\title{
Designing a programme for Sustainability in Vietnam: Smart Sustainable Vietnamese Cities, SSVC.
}

\section{Rietbergen, Martijn ${ }^{a}$; De la Poza, Elena ${ }^{b}$; Orozco-Messana, Javier ${ }^{c}$}

${ }^{a}$ Research Group New Energy in the City, Institute Engineering \& Design, Utrecht University of Applied Science, Netherlands; ${ }^{b}$ Center of Economic Engineering, Universitat Politècnica de València, Spain; ${ }^{c}$ Departamento de Ingeniería Mecánica y de Materiales, Universitat Politècnica de València, España,.

\begin{abstract}
This work deals with the design and development of the SSVC module, which is organised and implemented by European Higher Education Institutions in partnership with Vietnamese Universities. The reform of the Higher Education in Vietnam requires new pedagogical practices and methods which are used in the SSVC module. In addition, the process of design must include the adjustment of the European content and pedagogical methods into Vietnamese circumstances. Finally, the programme needs to be piloted and assessed.
\end{abstract}

Keywords: stakeholder; environment; Higher Education; sustainability, alliance. 


\section{Introduction}

Vietnam has been one of the world's most dynamic developing countries during the past two decades. Alongside significant economic growth, the urbanisation process in Vietnam is happening rapidly, creating significant pressure on the sustainability in urban areas. The transition towards smart sustainable Vietnamese cities is therefor a huge challenge. In this context, universities have the responsibility to update their curricula, tune their programmes to what the market requires, and thus educate competent professional, with the right knowledge, skills and attitude. One of the major concerns in the current Vietnamese teaching programs is limited tuning between education and the workplace. The design of a so-called hybrid learning environment (Zitter and Hoeve, 2012) can facilitate the proper transition of knowledge, skills and attitude between education and the workplace. European Higher Education Institutions have a long distance traveled in this direction and can foster and guide others into the right path.

This work deals with the process of design and production of guidelines for a programe of sustainability in Vietnam. The purpose of this programme is therefore to educate young professionals in the field of engineering / natural science that are able to develop integrated smart sustainable solutions for economic, social and environmental challenges in Vietnamese urban areas.

\section{The SSVC programme}

\subsection{Stakeholders of the programme}

The title of the programme relies on the contents of the course. The Smart Sustainable Vietnamese Cities is a 15 ECTS (European credit transfer and accumulation system), comparable to one one quarter of an academic year, about 400 study hours including contact hours, group work, self study. The SSVC programme will be offered by various Vietnamese universities as part of or as an add on to of existing bachelor programmes. The SSVC programme does not lead to a degree itself.

The involved Higher Education Institutions (HEIs) is a consortium of Vietnamese and European Universities. Following in table 1, the HEIs are detailed: 
Table 1. Involved HEIs in the SSVC programme

Hanoi University of Civil Engineering - HUCE - Vietnam

Danang University of Science and Technology - DUT - Vietnam

Ho Chi Minh City University of Natural Resources and Environment - HCMUNRE - Vietnam

Vietnam National University - VNU-HUS - Vietnam

Haiphong University - HU - Vietnam

Hue University of Sciences - HUS - Vietnam

Turun Ammattikorkeakoulu Oy - TUAS - Finland

Stichting Hogeschool Utrecht - HU - Netherlands

Universitat Politecnica de Valencia - UPV - Spain

The Manchester Metropolitan University - MMU - United Kingdom

Hochschule für Angewandte Wissenschaften - HAW - Germany

Source: Own performance.

The programme is intented to the be fully implemented in the academic year 2019-2020. Until 2019 the programme will be piloted. The target group are students in their 3rd or 4th year of programmes at at European Qualification Framework EQF-level-6; European Higher Education Area, QF- EHEA-First cycle = Bachelor.

The programme is composed of 5 courses (table 2), each of those have the same weight (2.5 credits in ECTS), with the exception of the last course, the urban sustainability challenge (5 ECTS). The development of each course was coordinated by one European HEI and one Vietnamese HEI.

Table 2. Course overview

\begin{tabular}{ll}
\hline \multicolumn{2}{c}{ Course name } \\
\hline SSVC Introduction and Methodology & HAW and VNU-HUS \\
Design for Social Sustainability & HU and DUT \\
Sustainable Entrepreneurship & MMU and HUCE \\
Engineering Sustainable Cities in Vietnam & UPV and HCMUNRE \\
The Urban Sustainability Challenge & TUAS and VNU-HUS \\
\hline
\end{tabular}




\subsection{Programme design process}

The design process of the programme involves four stages. Each of those stages requires a change of paradigm in the Vietnamese Higher Education system. The involvement of the Vietnamese HEIs is a key issue for the success of the implementation and development of the programme.The four stages are detailed as follows:

1. Understand the concept of hybrid learning environments. For this purpose the Zitter and Hoeve framework was applied, (Figure 1). In each course, learning activities should be represented and be aligned in each of the four quadrants.

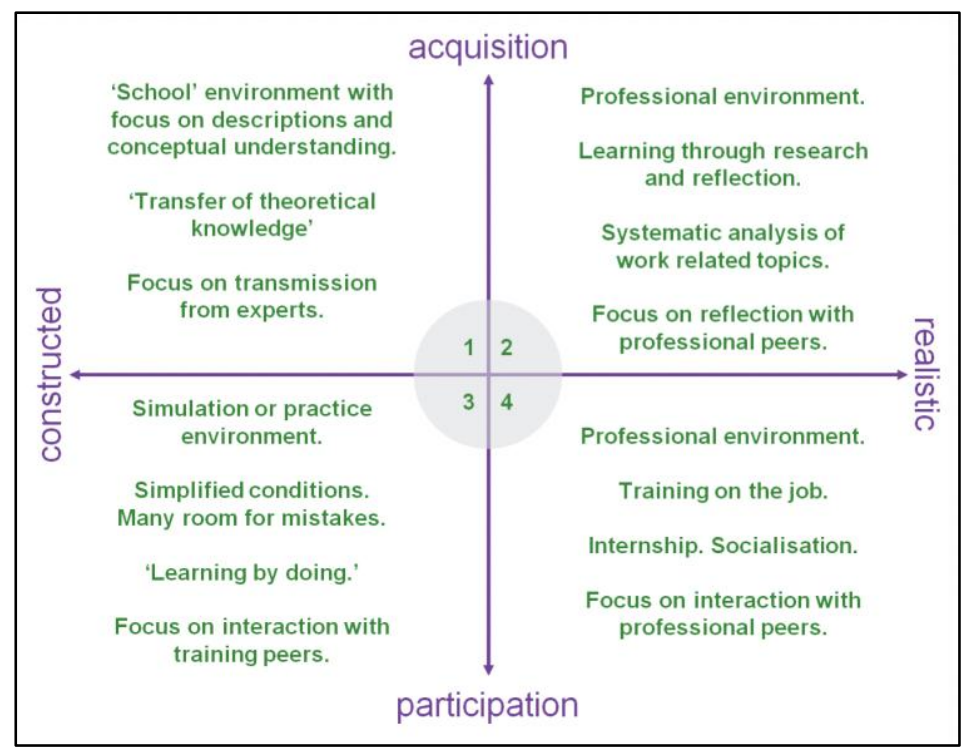

Figure 1. Hybrid Learning Environment. Source: Zitter, I. and A. Hoeve (2012).

2. Understand the concept of authentic tasks. The key element of the hybrid learning environment is the authentic task. The authentic task are assignments that are taken from practice. In other words these authentic task are original professional activities. The authentic tasks require further competencies in different domains, including specific knowledge, skills and attitude. The learning process to master the task should preferably takes place in all four quadrants of the hybrid learning environment.

3. Identify authentic tasks for the programme, preferably one per course. In table 3, examples of authentic tasks are described for each course and context. 
Table 3. Authentic tasks examples

\begin{tabular}{|c|c|c|}
\hline Course name & Example of authentic task & Context \\
\hline $\begin{array}{l}\text { SSVC introduction } \\
\text { and methodology }\end{array}$ & $\begin{array}{l}\text { Example: Quick scan of } \\
\text { sustainability problems }\end{array}$ & Any \\
\hline $\begin{array}{l}\text { Design for Social } \\
\text { Sustainability }\end{array}$ & $\begin{array}{l}\text { Example: Making a Social impact } \\
\text { assessment / Making a social design } \\
\text { for building new communities }\end{array}$ & $\begin{array}{l}\text { Students can choose one out of the } \\
\text { three authentic tasks that relate to: } \\
\text { 1) Waste / water; 2) Energy; 3) } \\
\text { Land use planning }\end{array}$ \\
\hline $\begin{array}{l}\text { Sustainable } \\
\text { Entrepreneurship }\end{array}$ & $\begin{array}{l}\text { Example: drawing up a waste } \\
\text { management plan, defining an energy } \\
\text { saving strategy for a building / } \\
\text { municipality ... }\end{array}$ & $\begin{array}{l}\text { Students choose one out of the } \\
\text { three authentic tasks that relate to: } \\
\text { 1) Waste / water; 2) Energy; 3) } \\
\text { Land use planning }\end{array}$ \\
\hline $\begin{array}{l}\text { Engineering } \\
\text { Sustainable Cities }\end{array}$ & $\begin{array}{l}\text { Example: Writing a business plan / } \\
\text { business model for an energy service } \\
\text { company }\end{array}$ & $\begin{array}{l}\text { Students choose one out of the } \\
\text { three authentic tasks that relate to: } \\
\text { 1) Waste / water; 2) Energy; 3) } \\
\text { Land use planning }\end{array}$ \\
\hline $\begin{array}{l}\text { The Urban } \\
\text { Sustainability } \\
\text { Challenge }\end{array}$ & & $\begin{array}{l}\text { Projects could relate to one of the } \\
\text { three topics 1) Waste / water; 2) } \\
\text { Energy; 3) Land use planning }\end{array}$ \\
\hline
\end{tabular}

Source: Own performance.

Then for each course the following aspects need to be defined: the title of each authentic task, a short description of the task, the environmental context, the most important domains of competence, the knowledge, skills and attitude required, and finally the assessment procedure.

Once the contents of the course are complete, the next stage will consist of sketching the students' learning process. Provide answers to the following questions, (Tafi, 2016):

1. how the student will learn through the hybrid learning model;

2. How is the teacher facilitating the learning? With what are students' learning?

3. With whom are they learning? Where are they learning? When are they learning?

Answers to these questions mean to apply new pedagogical techniques based on a more interactive relationship with the student. The future instructors of SSVC must train those pedagogical techniques. For this purpose, trainers perform several workshops. Each workshop is focused on a different methodology. After each workshop, there should be an assessmentin which participants should apply critical thinking about what has happened during it and the changes they have experienced as instructors. 
The participants need to answer to the following questions:

1. Which aspects of the workshop need improvement in your perspective?

2. Are there things that should be added?

3. What do you think of the quality of the output of the work delivered by the trainees?

4. What observations can you share about the trainees learning efforts/attitudes?

5. What important lessons can be learnt from the reactions of the participants?

6. To what extent did the content fit with the Vietnamese University context and cultural context?

7. What do you think the trainees specifically need as additional training as a follow up to continue with developing the course materials?

\section{Conclusions}

The main goal of the course development was to support the modernisation of Vietnamese partner university curricula. The activity aims to build the capacity of the universities in Vietnam and their stakeholders to give them the tools to enable a transition in Vietnam through a number of activities that educate professionals and students to develop viable solutions for smart sustainable cities.

This new cooperation between universities, enterprises and public bodies provides valuable opportunities for students to learn by designing solutions for environmental challenges in the cities as part of their Higher Education studies. In the longer term participants will form sustainable alliances, not only between universities in Vietnam but also between universities and enterprises at the regional, national and international level.

\section{References}

Lokhoff, J., Wegewijs, B., Durkin, K., Wagenaar, R., Gonzalez, J., Isaacs, A.K., Donà L. F., Gobbi, M. (2010).A Tuning Guide to Formulating Degree Programme Profiles Including Programme Competences and Programme Learning Outcomes. Deusto, Bilbao, Spain.

Mulder, H., Ten Cate, O., Daalder, R., \& Berkvens, J. (2010). Building a competencybased workplace curriculum around entrustable professional activities: The case of physician assistant training, Medical Teacher, 2,10, e453-e459.

Tafi, T. (2016). Introductory course on SSC. Overview on course content and timing. ESSENCE.

Zitter, I. and A. Hoeve (2012), "Hybrid Learning Environments: Merging Learning and Work Processes to Facilitate Knowledge Integration and Transitions", OECD Education Working Papers, No. 81, OECD Publishing. http://dx.doi.org/10.1787/5k97785xwdvf$\underline{\text { en }}$ 